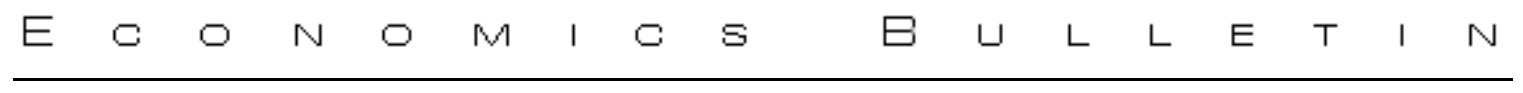

\title{
On the Smithian origins of "new" trade and growth theories
}

\author{
Aykut Kibritçioglu \\ University of Illinois at Urbana-Champaign and Ankara University
}

\begin{abstract}
Adam Smith is generally ignored as a trade theorist in textbooks and surveys because of the common belief that he only confirmed the rule of absolute advantages to explain structure of foreign trade. On the other hand, many textbooks and surveys on growth theories simply overlook Smith's significant contributions to growth theory. However, his vent-for-surplus approach may be interpreted as a pioneering study which stresses the importance of economies-of-scale in explaining the structure of trade. Furthermore, in Smith (1776), both learning by doing and economies-of-scale are crucial to explain long-run growth. This short paper addresses to the undeniable influence of Smith's concepts such as "extent of the market", "division of labor", "improved dexterity in every particular workman" and "simple inventions coming from workman" on both recent trade and growth models. The note mainly is based on a schematic outline of Smith's ideas on the nature and causes of the wealth of nations.
\end{abstract}

Citation: Kibritçioglu, Aykut, (2002) "On the Smithian origins of "new" trade and growth theories." Economics Bulletin, Vol. 2, No. 1 pp. $1-15$

Submitted: February 6, 2002. Accepted: May 20, 2002.

URL: http://www.economicsbulletin.com/2002/volume2/EB-02B00001A.pdf 


\section{Introduction}

Technological change and economies-of-scale are still at the forefront of research in economics, both in terms of their interactions and their role in explaining foreign trade and longrun economic growth. The level of technology, broadly speaking, may be defined as a stock or a combination of our knowledge and experiences on production process, product quality, organization of production and management, marketing, and services. ${ }^{1}$ This means that one can differentiate at least two types of innovations, which are the result of firms' introduction of new technologies commercially: process innovation and product innovation. A process innovation, or a unit cost reduction, caused by technological change induces an increase in the quantity of output, while keeping the product quality and both the quantities and qualities of inputs the same. A product innovation then includes only quality improvements in terms of the outputs. No matter what kind of innovations are considered, the determinants of technological progress or the causes of "increases" in the level of technology can be classified into two major groups: internal causes and external causes. The externality of determinants implies that the source of technological change is external to the relevant firm, as in the cases of technology transfer and imitation. Second, internal causes mainly cover learning by doing (also called experience, or time, economies) and research and development (R\&D) activities within the firm.

New trade and growth theorists make economies-of-scale and learning by doing an important part of their models of international trade and long-run growth. This note attempts to describe and discuss the main influence channels originating from Adam Smith's (1776) seminal ideas on "extent of the market", "division of labor", "improved dexterity in every particular workman" and "simple inventions coming from workman". The paper is organized as follows. Section 2 summarizes the "new" dimension of both recent trade theories and endogenous growth models. In Section 3, the Smithian origins of new trade theories (NTTs) are described with special reference to his vent-for-surplus model of trade. Then Section 4 briefly outlines Smith's ideas on economic growth in order to enlighten the Smithian origins of endogenous growth models more clearly. Finally, the possible influences of Smith (1776) on NTTs and new growth models are discussed in Section 5. Needless to say that this note aims at focusing only on the Smithian fundamentals of new trade and growth theories as schematized in Figure 1. That is, a thorough discussion of other possible theoretical influences stemming directly from other economists' (e.g., Young, Schumpeter, Kaldor and Arrow) works is ignored here for clarity.

\section{New Trade Theories and New Growth Models}

New theories of international trade developed by many economists (e.g., Grubel, Lloyd, Greenaway, Aquino, Tharakan, Krugman, Lancaster, Brander, Spencer, Helpman, Grossman, Eaton and Dixit) since the mid-1970s may be interpreted as a fruitful synthesis of the following two ideas: (1) Economies-of-scale, or increasing returns to scale, is one of the most important sources of international trade and specialization. (2) Issues of industrial organization can be modeled as the outcome of non-cooperative games among firms and possibly other players. In a sense, the latter approach is the essence of the new industrial organization approach of the 1970s. Its application to international trade issues contributed to emergence of two generations of NTTs.

The intra-industry trade literature forms the first generation of NTTs (e.g., Grubel and Lloyd, 1975). It primarily concentrates on the relative importance of the determinants of simultaneous exports and imports of the same, or similar, manufacturing products in a country. Product

1 This definition and the following classification are formulated at the firm level but they are easily applicable to the macroeconomic level. 
differentiation, economies-of-scale, demand structure (or income level) of individual countries, border trade (or transport costs), re-export, transaction costs, and intra-firm trade of multinational enterprises are among the major determinants considered in the literature. Second, the intra-industry trade literature focuses on the empirical relevance of two-way trade in time and space.

The second generation of NTTs is generally not theory but policy oriented because they are based on market failure arguments for protection. Market failure may stem from technological externalities or from economies-of-scale and imperfect competition. Externalities, or spillover effects, in the production process of technologies stimulated discussions on the necessity of protection of domestic high-tech industries and restructuring of economies by technological and educational policies accordingly. These government policies are aimed at creation of technological externalities through inducing R\&D activities and investment in human capital. In the literature, the necessity, or relevance, of protection of domestic oligopolists or monopolists is also discussed, mainly under the assumption of increasing returns to scale and imperfect competition within a game-theoretical framework. This second generation of NTTs is sometimes referred to as strategic-trade-policy or industrial-targeting literature. ${ }^{2}$

Investigation of sources of long-run economic growth and development has always been an interesting topic for economists. ${ }^{3}$ The neoclassical growth model is mainly developed by Ramsey (1928), Solow (1956), Swan (1956), Cass (1965), and Koopmans (1965). The basic assumptions of the one-sector neoclassical growth model are constant returns to scale, diminishing marginal productivity of capital, exogenous production technology, substitutability of capital and labor, and lack of an independent investment function. The standard neoclassical growth model implies that the steady state growth rate, aside from exogenous technological progress, is zero. That is, conventional macroeconomic policies such as government investment can affect the level of percapita income but they have no effect on the long run growth rate of the economy. Moreover, improvements in the production technology are not explicitly modeled; they are reduced to a "black box" in the model. The exogenous technological improvements, if continuous, can compensate for the negative effect of decreasing marginal productivity of capital thereby leading to long run growth. Finally, the exogenously determined constant population growth rate is the main determinant of per-capita real income level in many neoclassical growth models.

The standard neoclassical growth model implies that countries with the same steady-state capital per-worker but different initial relative factor endowments and per-capita incomes will grow at different rates to eventually reach the same per-capita income level. This so-called "absolute convergence" between fast-growing poor, and slow-growing rich countries is based on the assumption that technology, the saving rate, and population growth rate are all identical across countries, and that returns to capital are diminishing. The convergence hypothesis was to become a major point of disagreement with the subsequent endogenous-growth theory, in particular following Romer (1986) and Lucas (1988). Currently, it is generally accepted that there is more evidence in favor of a "conditional convergence"; e.g. Barro (1991), Mankiw et al. (1992), and Barro and Sala-i-Martin (1992). That is, countries with different parameters and

2 See, for example, Krugman (1979), Brander and Spencer (1984), Helpman and Krugman (1985), and Krugman (1989). For a survey of the strategic trade policy literature, see Baldwin $(1988,1992)$ or Brander $(1995)$.

3 Economic growth and development is a complicated process that falls into the domain of many disciplines in social sciences and humanities. For a survey of recent growth theories developed in an interdisciplinary fashion, see Kibritçioğlu and Dibooğlu (2001). 
different steady-state capital per-worker targets will grow at different rates but those with similar parameters will converge to reach the same per-capita output level.

Paul Romer, Robert Lucas and other advocates of endogenous growth theory argued that, unlike physical capital, human capital may be augmented by non-diminishing returns, which permits economic growth to continue indefinitely. Accordingly, technological progress occurs as a purposeful economic (R\&D) activity when profit-maximizing agents seek out newer and better products. Inventions are rewarded with an ex-post monopoly power through patents to cover the high cost of initial investments necessary to bring new products to the market. There is another dimension of the economics of new ideas or technology: innovations have a public component (externality) in that they raise the productivity of all subsequent innovators. Ultimately the growth rate of an economy depends on R\&D technology, the degree of firms' monopoly power (appropriability of new technologies) and time horizon of investors.

First generation endogenous growth models achieve positive and constant steady state growth rates both by assuming non-decreasing returns-to-scale and by endogenizing technological improvements. That is, technological spillover effects resulting from investments in R\&D (e.g., Romer, 1990, Aghion and Howitt, 1992, 1994, and Grossman and Helpman, 1989, 1990, 1991), human capital (e.g., Lucas, 1988, Stokey, 1988, 1991, Becker, Murphy and Tamura, 1990, and Young, 1991) or technological infrastructure (e.g., Barro, 1990) ensure a self-feeding growth process in the economy. Another class of models known as the "AK type," replaces the assumption of diminishing marginal productivity of capital with the non-diminishing marginal productivity of the accumulate-able factor of production to achieve positive and sustainable steady state growth rate in the economy (see Jones and Manueli, 1990, and Rebelo, 1991).

Endogenous growth models, no matter whether they are "scale" or "AK-type" models, emphasize the important role of governments' fiscal, technology, education and health policies in the process of economic development. They also leave some room to historical, cultural and sociological factors as determinants of long-run economic growth. Nevertheless, empirical evidence does not strongly support either the absolute convergence idea of some neoclassical models or the existence of increasing returns to scale in endogenous growth models. ${ }^{4}$ The criticism of the latter has recently led to the development of non-scale growth models, which is much closer to the neoclassical model (Turnovsky, 2000). Jones (1995), for example, argues that the steady state growth rate is independent of traditional macroeconomic policies. However, because of slow convergence speeds in the transition process, these policies can lead to remarkable long-run effects on the level of per-capita income.

Endogenous growth models developed within the framework of inter-temporal optimizing behavior of rational agents embody different intellectual influences. Some models can be broadly considered as an extension of the Schumpeterian or the institutional tradition. ${ }^{5}$ Some others have strong (neo-)Smithian or still a neoclassical background. Some of endogenous growth models are even called Harrod-type growth models. In the rest of this note, particularly the Smithian characteristics of new trade and growth models will be discussed. ${ }^{6}$

4 For a survey of empirical evidence for endogenous growth models, see Thirlwall and Sanna (1996).

5 Nelson and Winter (1982), Aghion and Howitt (1992, 1994), and Grossman and Helpman (1991) represent the main neoSchumpeterian versions of endogenous growth models.

6 Since early 1990s, a new field of research, often described as the "new economic geography", has emerged with significant contributions of Paul Krugman (see Krugman, 1998, and Martin, 1999). Although this literature methodologically benefits from the NTTs and endogenous growth models, the discussion of influences of Smith (1776) here is limited to his possible effects on the NTTs and new growth theory. 


\section{The Role of International Trade in Adam Smith's World}

Neither mercantilists nor physiocrats were able to make essential contributions to the pure, or real, international trade theory before David Ricardo, who stressed the role of comparative advantages in explaining structure of foreign trade. Ricardo's static approach of comparative advantages was based on the exogenity of division of labor between nations. That is, they were created by international differences in exogenous factor-productivities.

The so-called rule of the 18. century prior to Ricardo states that foreign trade is gainful for a nation if and only if those products are imported into the country which can not produced domestically or which are produced more expensively in comparison to that in the rest of the world (Viner, 1937). Also Adam Smith in his An Inquiry into the Nature and Causes of the Wealth of Nations seems to have overlooked the possibility that a country, in which all products are produced by using more inputs per output as in the rest of the world, can gain from free trade, i.e. trade structure depends on comparative advantages: ${ }^{7}$

"It is the maxim of every prudent master of a family, never to attempt to make at home what it cost him more to make than to buy. [...] What is prudence in the conduct of every private family, can scarce be folly in that of a great kingdom. If a foreign country can supply us with a commodity cheaper than we ourselves can make it, better buy it of them with some part of the produce of our own industry, employed in a way in which we have some advantage." (Smith, [1776] 1937: 424)

In fact, Smith was very close to the idea of comparative advantages before Ricardo. He wrote: "The most opulent nations [...] generally excel all their neighbours in agriculture as well as in manufactures; but they are commonly more distinguished by their superiority in the latter than in the former." (Smith, [1776] 1937: 6)

Smith believed that a young country's most important advantage naturally lies in agriculture because of the availability of abundant and cheap land that can be used for agricultural production. In his age, labor was cheap, and land was scarce and expensive in Europe. Therefore, the (comparative) advantage of European nations was to produce manufacture products (Hollander, 1973). However, he seems to have missed the chance to be the first economist who stated the rule of comparative advantages explicitly (Staley, 1973, and Bloomfield, 1975). Perhaps, this is the main reason, as argued in Myint (1977), Hong (1984) and Gomes (1987), why Smith's ideas on foreign trade are generally ignored, or associated only to the concept of absolute advantages, in textbooks ${ }^{8}$ and theoretical surveys ${ }^{9}$ on international trade. Bloomfield (1975), for example, states:

"Various writers, while acknowledging his undeniable importance and influence as an economist, have referred to shortcomings, oversimplifications, and even inconsistencies in his theorizing on foreign trade. Others have questioned the originality of his free-trade ideas."

Actually, Smith's (1776) main contribution to international trade theory cannot be found in his static economic analysis. ${ }^{10}$ It is his dynamic approach to extent of the market, which is essential for the modern trade theory. ${ }^{11}$ According to him, the principle of free trade was nothing more than the application of specialization and division of labor to a global scale (Gomes, 1987). That is, he had not seen any difference between domestic and foreign trade. The reason for a surplus productive capacity was the narrowness of the domestic market. ${ }^{12}$ By being able to export the products of this excess capacity that are not demanded in the home market, or simply by

\footnotetext{
7 See Bastable (1893), Viner (1937), Staley (1973), Hong (1984), Koo (1985), and Gomes (1987).

8 See, for example, Yarbrough and Yarbrough (1988), Patterson (1989), Krugman and Obstfeld (2000), and Salvatore (2000).

9 See, for example, Haberler (1961), Chipman (1965a, 1965b, 1966), and Baldwin (1989).

10 Smith's ideas on foreign trade can be found especially in the following chapters of his Wealth of Nations: Chapter 11 of Book I; Chapter 5 of Book II, Chapters 3 and 4 of Book III, and Chapters 1-4 and 8 of Book IV.

11 See also Myint (1958), Hollander (1973), Bloomfield (1975), Myint (1977), Ertek (1984) and Hong (1984).

12 See Myint (1958), Bloomfield (1975) and Gomes (1987).
} 
extending the market, ${ }^{13}$ the division of labor would be improved and the productivity of nation increased, thus resulting in an increased wealth of a nation. But in the case of being not able to export these "superfluous" products, the factors of production of this country could be underemployed. Exports, therefore, played the role of a vent-for-surplus, and ensured the fullemployment of factors of production in the Wealth of Nations:

"When the produce of any particular branch of industry exceeds what the demand of the country requires, the surplus must be sent abroad, and exchanged for something for which there is a demand at home. Without such exportation, a part of the productive labour of the country must cease, and the value of its annual produce diminish. The land and labour of Great Britain produce generally more corn, woolens, and hard ware, than the demand of the home-market requires. The surplus part of them, therefore, must be sent abroad, and exchanged for something for which there is a demand at home." (Smith, [1776] 1937: 353)

"In every period, indeed, of every society, the surplus part both of the rude and manufactured produce, or that for which there is no demand at home, must be sent abroad in order to be exchanged for something for which there is some demand at home." (Smith, [1776] 1937: 359)

"Between whatever places foreign trade is carried on, they all of them derive two distinct benefits from it. It carries out that surplus part of the produce of their land and labour for which there is no demand among them, and brings back in return for it something else for which there is a demand. It gives a value to their superfluities, by exchanging them for something else, which may satisfy a part of their wants, and increase their enjoyments. By means of it, the narrowness of the home market does not hinder the division of labour in any particular branch of art or manufacture from being carried to the highest perfection. By opening a more extensive market for whatever part of the produce of their labour may exceed the home consumption, it encourages them to improve its productive powers, and to augment its annual produce to the utmost, and thereby to increase the real revenue and wealth of the society." (Smith, [1776] 1937: 415)

Therefore, these ideas of Smith on external trade has been called vent-for-surplus model by Mill ([1844] 1909: 579-580) and his followers, such as Williams (1929) and Myint (1958). According to Myint (1958), Smith's model was very suitable to explain at least a specific part of the trade of developing countries. ${ }^{14}$ In today's terminology, Smith described a dynamic, selffeeding process of trade driven by economies-of-scale and imperfect competition that can be thus interpreted as an attempt towards endogenization of comparative advantage between countries.

\section{Smith on Long-Run Economic Growth}

In the economics literature, it is generally argued that, in Smith (1776), capital accumulation plays a leading role in the economic growth process of a country, and technological progress passively follows it (Brewer, 1991, and Ahmad, 1996). But Barkai (1969) suggests that in the Wealth of Nations technological change is more important than other factors to explain the nature and causes of the wealth of nations. The determinants of economic growth and development in Smith's world and their complicated interactions may be schematically summarized as shown in Figure 2. Obviously, this figure is based on the thought that, according to Smith (1776), not only capital accumulation but also technological progress, and both institutional and social factors play a crucial role in the economic development process of a country. Furthermore, it is shown that his thoughts were strongly influenced by the natural philosophy of his age (see also Tezel, 1995).

Apparently, Smith (1776) attributes an essential role to technological change in the form of learning by doing in the determination process of the wealth of nations. Furthermore, he does not fully ignore the role of machine-makers and philosophers in inventing new machines; he

13 Smith (1776) underlined also the effects of geographical distance and transportation costs on trade structure and trade volume. He expressed that trading with neighboring countries would be advantageous in comparison to trading with other countries because of the low transportation costs. The division of labor would be limited by the scale of the market, while the transportation costs were one of the main determinants of the extent of the market. According to Smith, the transportation costs of primary products and rude manufactured products were lower than of other products. See also Bloomfield (1975) and Myint (1977) on this issue.

14 The apparent inconsistency of Smith's vent-for-surplus model with the rest of his analysis may partially be eliminated by considering the role of joint products in his explanations on foreign trade (see Kurz, 1992, and Elmslie, 1996). 
interprets their contributions as exception but as a more powerful source of technological change. That is, innovations in the form of simple inventions or improvements in existing machines come principally from (the rise of experiences of) "workman." More fundamental inventions, however, are made by philosophers and machine-makers (see also Figure 2 ). ${ }^{15}$ Smith combines the concept of learning by doing with economies-of-scale through the concept of division of labor, which in turn only can be improved by extending the market. Under conditions of increasing returns to scale, the experience, or cumulative output, of workers rises. This leads to technological change. As a response, technological change in terms of learning by doing (and in the form of inventing new machines or improving an old one) stimulates the division of labor and specialization through increases in wealth, profits, and the process of capital accumulation.

Note that Smith distinguishes between three stages of economic growth (see Figure 3 ). In his opinion, nations like China and Turkey were at "a low level equilibrium trap" (Stage A) because of "bad-governance" and an insufficiency in maintaining basic human rights and freedoms or "property rights" in modern parlance. This was due to cultural and institutional backwardness of these countries. Leading nations in his age were England and North America but they were only at the second stage of development (Stage B). They were still in a "natural freedom" environment, and therefore, in an ongoing economic growth process. Smith believed that no country in the $18^{\text {th }}$ century was at the third stage of economic growth (Stage C). According to him, the nature limits economic growth beyond a certain level. Falling profit rates along the growth path of an economy, changes in the relative factor scarcity, and decreases in profitable investment opportunities all play a significant role in constraining economic growth. These limitations of nature arise from limited land endowment, lack of favorable conditions, and both climate and geographical location of the country. Thus, every growing economy, had to slow down and stop at an upper limit of development. The notion of an upper limit to growth perhaps is related to the agrarian based society of Smith's age. Smith (1776) was aware of the possibility of extending the natural limits of a country by technological improvements in the manufacturing industry, which in turn was a result of learning by doing among others. However, one should not overestimate his views on the role of technological development as a determinant of economic growth.

\section{Concluding Discussion}

This short paper addresses to the significant influence of Smith's concepts of extent of the market, division of labor, improved dexterity in every particular workman, and simple inventions coming from workman (see Figure 2) on new trade and growth models (see Figure 1). ${ }^{16}$ Obviously, these terms seem to have survived due to the undeniable contributions of many economists after Adam Smith. For example, List (1841), Young (1928), Kaldor (1957, 1961), Schultz (1960), and Arrow (1962) stressed the importance of spillover effects of investment in human capital, R\&D or infrastructure. Young (1928) and Ohlin (1933), on the other hand, enhanced strongly Smith's ideas on extent of the market and division of labor. Today economists label Smith's concepts mentioned above as "economies-of-scale," "spillover effects," "learning by doing" or "learning by using." NTTs and endogenous growth models developed since mid1970s are principally based on technological externalities, increasing returns to scale (or economies-of-scale) and imperfect competition. Although the two concepts, learning by doing and economies-of-scale, easily may be dated back up to Adam Smith's the Wealth of Nations

\footnotetext{
15 Elmslie (1994) argues that for Smith the nature of technical progress was an ever-evolving process endogenous to the division of labor. In Smith (1776), increasing returns is not considered independently from technological progress.

${ }^{16}$ For an interesting paper on the relevance and originality of endogenous growth models, see Kurz (1997).
} 
from 1776, it should be noted that a specific part of the strategic-trade-policy literature originates from Alexander Hamilton's (1790) and Friedrich List's (1841) seminal ideas on protection of infant industries (see Kibritçioğlu, 1993). ${ }^{17}$

Among others, Figure 1 incorporates the causal link running from foreign trade to economic growth that still provides an interesting topic to many economists. Recently, some economists empirically investigated the interaction between trade and growth in the context of trade liberalization. ${ }^{18}$ For example, Rivera-Batiz and Romer $(1991,1994)$, and Devereux and Lapham (1994) discuss whether, in a world with two similar, developed economies, economic integration can cause a permanent increase in the worldwide rate of growth. Their study is based on the premise that $R \& D$ is the main source of economic growth, following the tradition of some endogenous growth models. Nevertheless, this issue is also not new. We know that Smith (1776) and many economists following him discussed the relevance of growth stimulating effects of trade.

Finally, one may argue that Smith (1776) affected many economists of the last two decades through another channel, which is presented by Piero and Sabel (1984) (see also Figure 1). In their book, the authors point out the recent decline of mass production systems and the rise of flexible production systems. ${ }^{19}$ Flexible production systems encourage the establishment of multiproduct factories or firms that operate under conditions of economies-of-scope. At the plant level, economies-of-scope can be achieved if one simultaneously can produce more than one product (or different models of a specific product) by lower unit costs in comparison to the production of each individual good in a different plant. The concept of economies-of-scope actually can be traced back to Schumpeter's evolutionary model of "creative destruction" and monopolistic competition.

Edwin Cannan (1924: 257) reports that Alfred Marshall declared as follows at the Cambridge meeting of the British Association in 1904:

"I verily believe that everything what later economists have discovered is in Adam Smith."20

Even though some economists may find this remark too exaggerated, one can easily conclude that Smith's (both direct and indirect) influences on new trade and growth models are undeniable. Following particularly Adam Smith, new trade and growth theorists too seem to have made economies-of-scale and learning by doing an important part of their models of international trade and long-run growth.

\footnotetext{
${ }^{17}$ For a discussion on progenitors of new trade theories, see Maneschi (2000).

18 In his survey article, Dowrick (1997) states that an important class of modern trade-growth models follows Adam Smith in emphasizing the role of trade in enabling specialization which yields increases in productivity through learning by doing or through specialization in research. They rely on spillover and/or feedback mechanisms to generate cumulative increases in productivity and specialization.

19 Their approach is sometimes called new-Smithian approach of flexible specialization (see Taymaz, 1993).

${ }^{20}$ See also Reisman (1991) on this remark.
} 


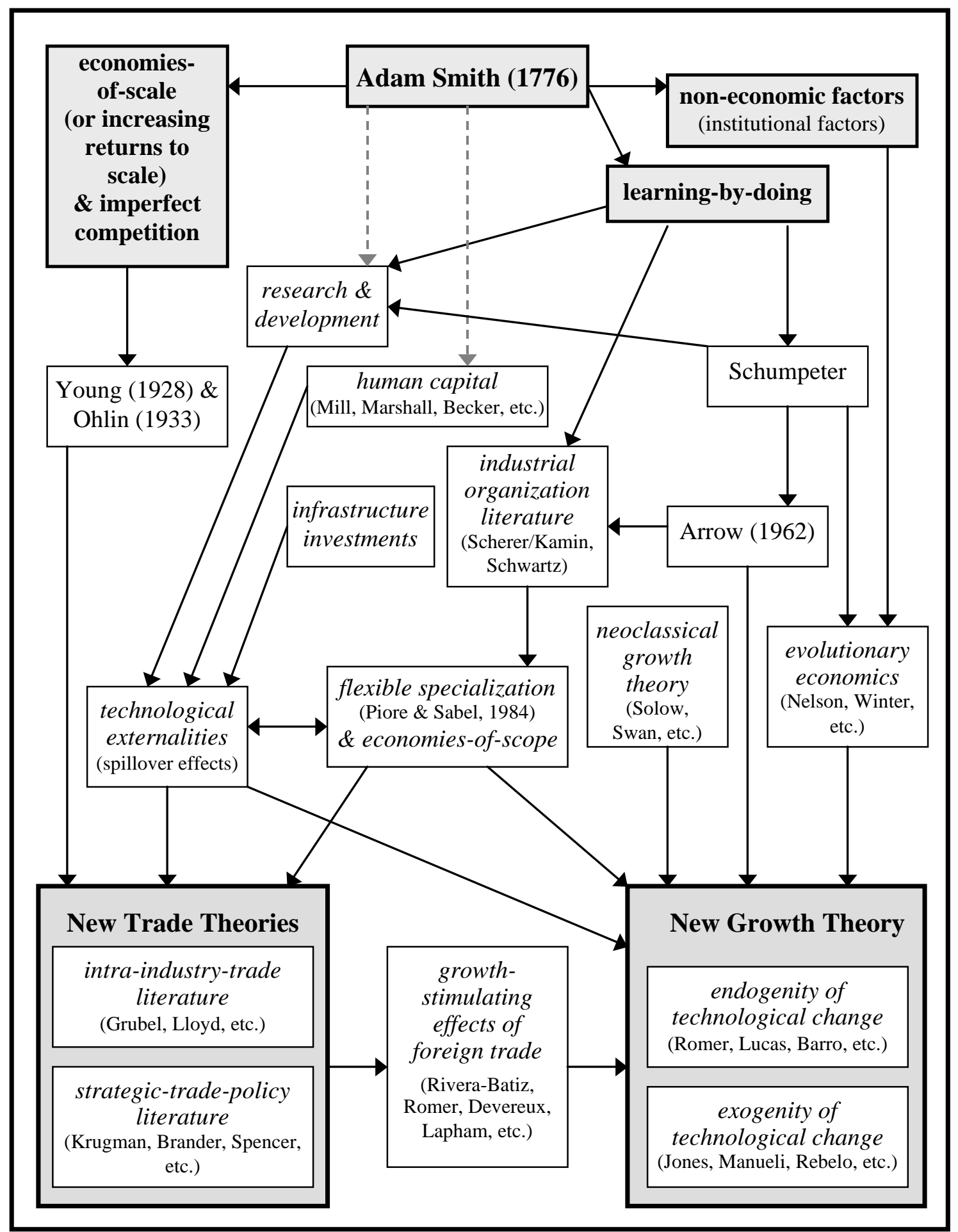

Figure 1: The Smithian Origins of New Trade Theories and Endogenous Growth Models

Note: For clarity, this scheme ignores the possible contributions of some of the post-Smith economists and the bilateral interactions between their ideas. Note that in the figure secondary, or weak, causal relations are shown with dashed gray arrows instead of solid black arrows. 


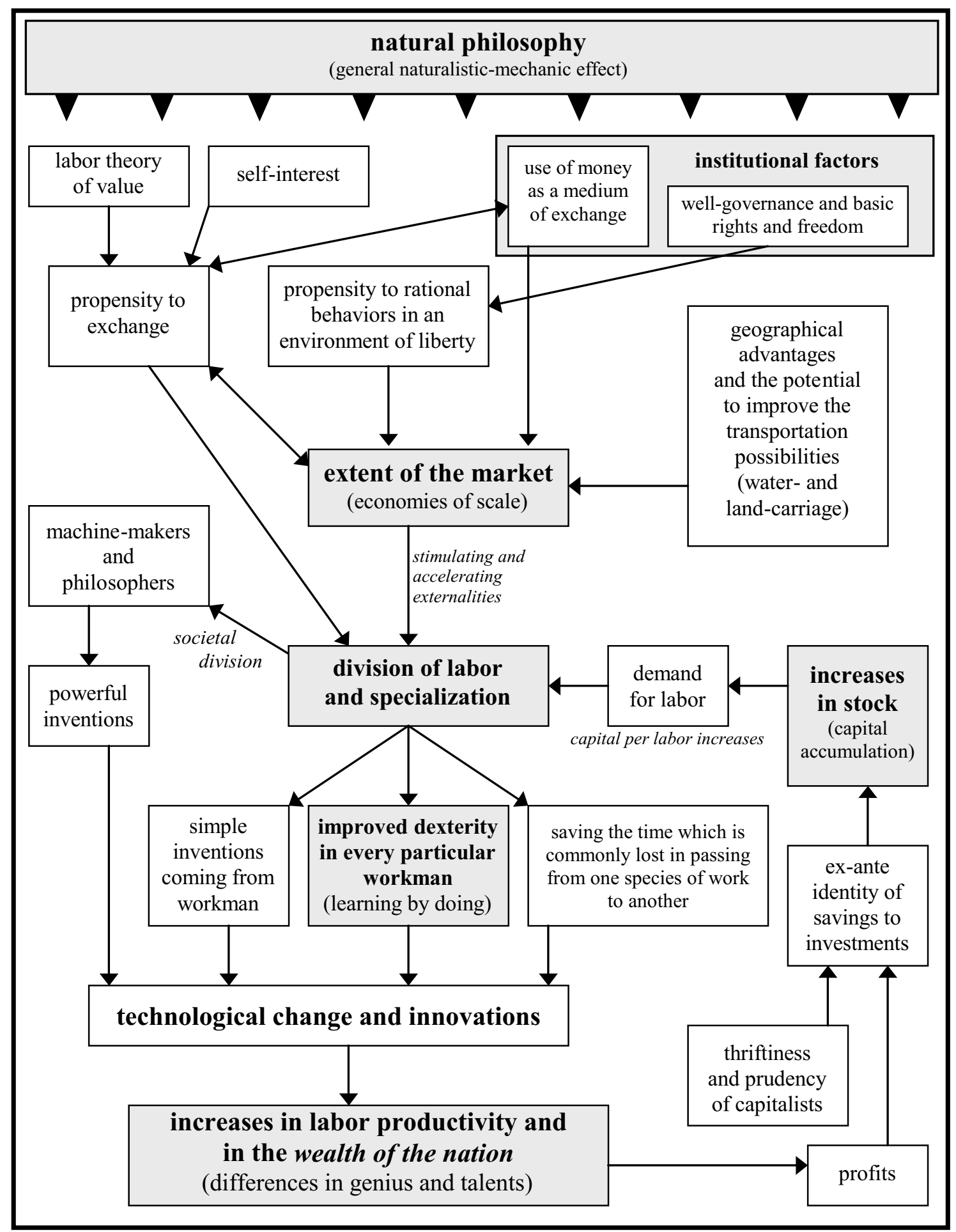

Figure 2: The Nature and Causes of the Wealth of a Nation According to Smith (1776)

Note: To ensure the clarity of the outline, some possible interactions or feedback effects are ignored in the figure. 


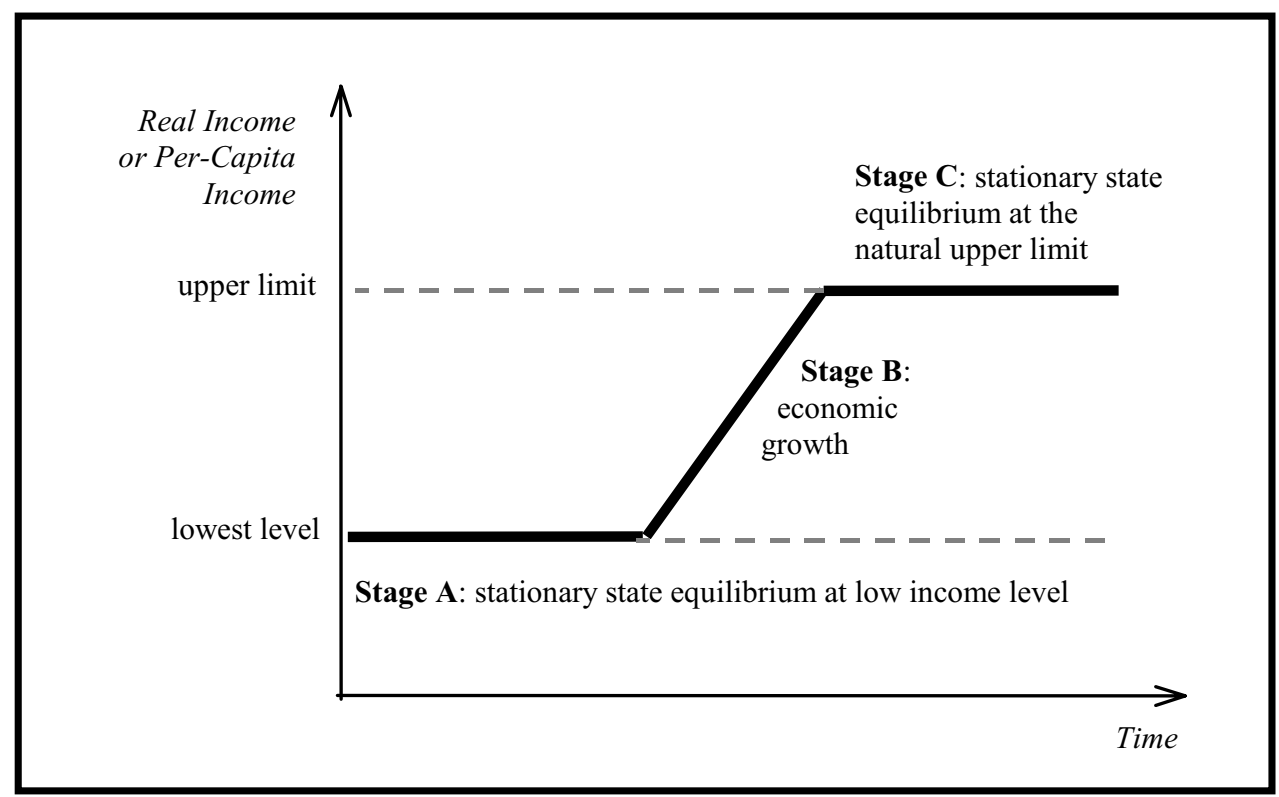

Figure 3: Three Stages of Economic Growth According to Smith (1776)

Source: adapted from Tezel (1995). 


\section{References}

Aghion, P., and P. Howitt (1992) "A Model of Growth Through Creative Destruction," Econometrica 60 (2), 323-51.

Aghion, P., and P. Howitt (1994) "Endogenous Technical Change: The Schumpeterian Perspective," in Economic Growth and the Structure of Long-Term Development by L. L. Pasinetti and R. M. Solow, Eds., London: Macmillan.

Ahmad, S. (1996) "Smith's Division of Labor and Rae's Invention: A Study of the Second Dichotomy, with an Evaluation of the First," History of Political Economy 28 (3), 441-58.

Arrow, K. (1962) "The Economic Implications of Learning by Doing," Review of Economic Studies 29 (3), 155-173.

Baldwin, R. E. (1988) "Evaluating Strategic Trade Policies," Aussenwirtschaft 43 (1-2), 207-30.

Baldwin, R. E. (1989) "Structural Change and Patterns of International Trade," in Causes of Changes in the Structure of International Trade, 1960-85 by J. Black and A. I. MacBean, Eds., London: The Macmillan Press, 12-23.

Baldwin, R. E. (1992) “Are Economists’ Traditional Trade Policy Views Still Valid?” Journal of Economic Literature, 30 (2), 804-29.

Barkai, H. (1969) "A Formal Outline of a Smithian Growth Model," Quarterly Journal of Economics 83 (3), 396-414.

Barro, R. J. (1990) "Government Spending in a Simple Model of Endogenous Growth," Journal of Political Economy, 98 (5), 103-26.

Barro, R. J. (1991) "Economic Growth in a Cross Section of Countries," Quarterly Journal of Economics 106 (2), 407-44.

Barro, R. J., and X. Sala-i-Martin (1992) "Convergence" Journal of Political Economy, 100 (2), 223-252.

Bastable, C. F. ([1893] 1903) The Theory of International Trade with Some Applications to Economic Policy, London: Macmillan.

Becker, G. S., K. M. Murphy, and R. Tamura (1990) "Human Capital, Fertility, and Economic Growth," Journal of Political Economy 98 (5), 12-37.

Bloomfield, A. I. (1975) "Adam Smith and the Theory of International Trade," in Essays on Adam Smith by A. S. Skinner and T. Wilson, Eds., Oxford: Clarendon Press, 455-81.

Brander, J. A. (1995) "Strategic Trade Policy," in: Handbook of International Economics, Volume 3, ed. by G. M. Grossman and K. Rogoff, Amsterdam: Elsevier, 1395-455.

Brander, J. A., and B. J. Spencer (1983) "International R\&D Rivalry and Industrial Strategy," Review of Economic Studies 50 (4), 707-22.

Brander, J.A., and B. J. Spencer (1984) "Tariff Protection and Imperfect Competition," in Monopolistic Competition and International Trade by H. Kierzkowski, Ed., Oxford: Clarendon Press.

Brewer, A. (1991) "Economic Growth and Technological Change: John Rae's Critique of Adam Smith," History of Political Economy 23 (1), 1-11.

Cannan, E. (1924) “Alfred Marshall 1842-1924,” Economica, 0 (12), 257-261.

Cass, D. (1965) “Optimum Growth in an Aggregative Model of Capital Accumulation," Review of Economic Studies, 32 (3), 233-240.

Chipman, J. S. (1965a) "A Survey of the Theory of International Trade: Part 1, The Classical Theory," Econometrica 33 (3), 477-519. 
Chipman, J. S. (1965b) "A Survey of the Theory of International Trade: Part 2, The NeoClassical Theory," Econometrica 33 (4), 685-760.

Chipman, J. S. (1966) "A Survey of the Theory of International Trade: Part 3, The Modern Theory," Econometrica 34 (1), 18-76.

Devereux, M. B., and B. J. Lapham (1994) "The Stability of Economic Integration and Endogenous Growth," Quarterly Journal of Economics 109 (1), 299-305.

Dowrick, S. (1997) "Trade and Growth: A Survey," in Technology and International Trade by J. Fagerberg, Ed., Cheltenham \& Brookfield: Edward Elgar, 107-26.

Elmslie, B. (1994) "The Endogenous Nature of Technological Progress and Transfer in Adam Smith's Thought", History of Political Economy 26 (4), 649-63.

Elmslie, B. (1996) "The Role of Joint Products in Adam Smith's Explanation of the 'Vent-forSurplus Doctrine," History of Political Economy 28 (3), 513-23.

Ertek, T. (1984) The Problem of Scale in Industrialization, and Turkey (in Turkish), Istanbul: Industrial Chamber of Istanbul.

Gomes, L. (1987) Foreign Trade and the National Economy: Mercantilist and Classical Perspectives, London: Macmillan.

Gomes, L. (1990) Neoclassical International Economics: An Historical Survey, London: Macmillan.

Grossman, G. M., and E. Helpman (1989) "Product Development and International Trade," Journal of Political Economy 97 (6), 1261-83.

Grossman, G. M., and E. Helpman (1990) "Comparative Advantage and Long-Run Growth," American Economic Review 80 (4), 796-815.

Grossman, G. M., and E. Helpman (1991) Innovation and growth in the global economy, Cambridge, Mass.: MIT Press.

Grossman, G. M., and E. Helpman (1994) "Endogenous Innovation in the Theory of Growth," The Journal of Economic Perspectives 8 (1), 23-44.

Grubel, H. G., and P. J. Lloyd (1975) Intra-Industry Trade: The Theory and Measurement of International Trade in Differentiated Products, London.

Haberler, G. (1961) A Survey of International Trade Theory, Princeton: Princeton University, Special Papers in International Finance, No. 1, reprinted in Selected Essays of Gottfried Haberler by A. Y. Koo, Ed., 1985, Cambridge, Mass., and London: MIT Press, 55-108.

Hamilton, A. ([1790] 1985) "Report on Manufactures," reprinted in Selected Writings and Speeches of Alexander Hamilton by M. J. Frisch, Ed., Washington, DC, and London: American Enterprise Institute for Public Policy Research, 1985, 277-318.

Helpman, E., and P. Krugman (1985) Market Structure and Foreign Trade. Cambridge, Mass.: MIT Press.

Hollander, S. (1973) The Economics of Adam Smith, Toronto, Buffalo: University of Toronto Press.

Hong, W. (1984) "A Note on Adam Smith and International Trade," Korean Economic Journal 23 (2), 195-202.

Jones, C. I. (1995) “Times Series Tests of Endogenous Growth Models," Quarterly Journal of Economics 110 (2), 495-525.

Jones, L. E., and Manuelli, R. (1990) "A Convex Model of Equilibrium Growth: Theory and Policy Implications," Journal of Political Economy 98 (5), 1008-38.

Kaldor, N. (1957) “A Model of Economic Growth,” Economic Journal 67 (268): 591-624. 
Kaldor, N. (1961) "Capital Accumulation and Economic Growth," in The Theory of Capital by F. A. Lutz and D. C. Hague, Eds., New York, NY: St. Martin's.

Kibritçioğlu, A. (1993) "Friedrich List's Infant Industry Argument and its Alternatives" (in Turkish), Hazine ve Dış Ticaret Dergisi 0 (16): 67-95.

Kibritçioğlu, A., and S. Dibooğlu (2001) "Long-Run Economic Growth: An Interdisciplinary Approach," Knowledge, Technology and Policy 13 (4), 59-70.

Koopmans, T. C. (1965) "On the Concept of Optimal Economic Growth," in The Econometric Approach to Development Planning. Amsterdam: North Holland.

Krugman, P. R. (1979) "Increasing Returns, Monopolistic Competition, and International Trade," Journal of International Economics 9 (4), 469-79.

Krugman, P. R. (1989) "New Trade Theory and the Less Developed Countries," in Debt, Stabilization and Development (Essays in Memory of Carlos Díaz-Alejandro) by G. Calvo et al., Eds., Cambridge, Mass.: Basil Blackwell and World Institute for Development Economics Research of The UN University, 347-65.

Krugman, P. R. (1998) "What's New about the New Economic Geography," Oxford Review of Economic Policy 14 (2), 7-17.

Krugman, P. R., and M. Obstfeld (2000) International Economics: Theory and Policy, New York, NY: Addison Wesley Longman, $5^{\text {th }}$ edition.

Kurz, H. D. (1992) "Adam Smith on Foreign Trade: A Note on the 'Vent-for-Surplus' Argument," Economica 59 (236), 475-81.

Kurz, H. D. (1997) "What Could the 'New' Growth Theory Teach Smith or Ricardo," Economic Issues 2 (2), 1-20.

List, F. ([1841] 1959) Das nationale System der politischen Ökonomie, Basel and Tübingen: Kyklos \& Mohr.

Lucas, R. E. (1988) "On the Mechanics of Economic Development," Journal of Monetary Economics 22 (1), 3-42.

Maneschi, A. (2000) "How New is the "New Trade Theory" of the Past two Decades?" Department of Economics, Vanderbilt University, Working Paper No. 00-W27.

Mankiw, N. G., D. Romer, and D. N. Weil (1992) "A Contribution to the Empirics of Economic Growth," Quarterly Journal of Economics 107 (2), 407-437.

Martin, R. (1999) “"The New "Geographical Turn' in Economics: Some Critical Reflections," Cambridge Journal of Economics 23 (1), 65-91.

Mill, J. S. ([1844] 1909) Principles of Political Economy with Some Applications to Social Philosophy, edited by W. J. Ashley, London.

Myint, H. (1958) “The 'Classical Theory' of International Trade and the Underdeveloped Countries," Economic Journal 68 (2), 317-37.

Myint, H. (1977) "Adam Smith's Theory of International Trade in the Perspective of Economic Development," Economica 44 (3), 231-48.

Nelson, R. R., and S. G. Winter (1982) An Evolutionary Theory of Economic Change, Cambridge: The Belnap Press of Harvard University Press.

Ohlin, B. ([1933] 1952) Interregional and International Trade, Cambridge: Harvard University Press.

Patterson, S. (1989) The Microeconomics of Trade, Kirksville: The Thomas Jefferson University Press.

Piore, J. M., and F. C. Sabel (1984) The Second Industrial Divide: Possibility for Prosperity, New York, NY: Basic Book Publications. 
Ramsey, F. (1928) “A Mathematical Theory of Saving," Economic Journal 38 (152), 543-559.

Rebelo, S. (1991) "Long-Run Policy Analysis and Long-Run Growth," Journal of Political Economy 99 (3), 500-21.

Reisman, D. A. (1991) "Alfred Marshall and Adam Smith," European Economic Review 35 (2/3), 323-32.

Rivera-Batiz, L. A., and P. M. Romer (1991) "Economic Integration and Endogenous Growth," Quarterly Journal of Economics 106 (2), 531-55.

Rivera-Batiz, L. A., and P. M. Romer (1994) "Economic Integration and Endogenous Growth: An Addendum," Quarterly Journal of Economics 109 (1), 307-08.

Romer, P. M. (1986) "Increasing Returns and Long-Run Growth," Journal of Political Economy 94 (5), 1003-37.

Romer, P. M. (1990) “Endogenous Technological Change,” Journal of Political Economy 98 (5), 71-102.

Romer, P. M. (1994) "The Origins of Endogenous Growth," The Journal of Economic Perspectives 8 (1), 3-22.

Salvatore, D. (2000) International Economics, New York, NY: Wiley, 7th Edition.

Schultz, T. W. (1960) "Capital Formation by Education," Journal of Political Economy 68 (6), 571-83.

Smith, A. ([1776] 1937) An Inquiry into the Nature and Causes of the Wealth of Nations, edited by E. Cannan, New York, NY: Modern Library.

Solow, R. (1956) "A Contribution to the Theory of Economic Growth," Quarterly Journal of Economics 70 (1), 65-94.

Staley, C. E. (1973) “A Note on Adam Smith's Version of the Vent for Surplus Model,” History of Political Economy 5 (3), 438-48.

Stokey, N. L. (1988) "Learning by Doing and the Introduction of New Goods," Journal of Political Economy 96 (4), 701-17.

Stokey, N. L. (1991) "Human Capital, Product Quality, and Growth," Quarterly Journal of Economics 106 (2), 587-616.

Swan, T. W. (1956) "Economic Growth and Capital Accumulation," Economic Record 32 (63), 334-361.

Taymaz, E. (1993) “Crisis and Technology” (in Turkish), Toplum ve Bilim Dergisi 56-61 (0), 541.

Tezel, Y. S. (1995) Economic Growth (in Turkish), Ankara: Imaj.

Thirlwall, A. P., and G. Sanna (1996) "The Macro Determinants of Growth and 'New' Growth Theory: An Evaluation and Further Evidence," in Employment, Economic Growth, and the Tyranny of the Market (Essays in Honour of Paul Davidson), Volume 2, by P. Arestis, Ed., Cheltenham and Brookfield: Edward Elgar, 131-56.

Turnovsky, S. J. (2000) "Growth in an Open Economy: Some Recent Developments," NBB Working Paper No. 5, Brussels: National Bank of Belgium.

Viner, J. (1937) Studies in the Theory of International Trade, New York, NY: Harper.

Williams, J. H. (1929) “The Theory of International Trade Reconsidered," Economic Journal 39 (2), 195-209.

Yarbrough, B. V., and R. M. Yarbrough (1988) The World Economy: Trade and Finance, New York, NY: The Dryden Press.

Young, A. A. (1928) "Increasing Returns and Economic Progress," The Economic Journal 38 (4), 527-42. 
Young, A. A. (1991) "Learning by Doing and the Dynamic Effects of International Trade," Quarterly Journal of Economics 106 (2), 369-406. 